\title{
Resistance to Puccinia polysora in Maize Accessions
}

J. Alicia Chávez-Medina and Norma E. Leyva-López, Departamento de Agropecuario, Centro Interdisciplinario de Investigación para el Desarrollo Integral Regional-IPN, Unidad Sinaloa, Guasave, Sinaloa, Mexico; and Jerald K. Pataky, Department of Crop Sciences, University of Illinois, Urbana 61801

\begin{abstract}
Chávez-Medina, J. A., Leyva-López, N. E., and Pataky, J. K. 2007. Resistance to Puccinia polysora in maize accessions. Plant Dis. 91:1489-1495.

A number of potential sources of general and specific resistance to southern corn rust were identified from 1,890 plant introduction accessions that were screened for reactions to Puccinia polysora race 9. Resistance appeared to differ among four accessions on which uredinia were not observed in initial screenings. Resistance to P. polysora in PI 186215 (Argentine inbred 2-687) was a chlorotic fleck, hypersensitive reaction that was conditioned by a single, dominant gene that was allelic with or very closely linked to the Rpp9 gene based on tests of allelism. All but 3 of 2,357 testcross progeny, (inbred 2-687 $\times R p p 9) \times \mathrm{P}_{\mathrm{S}}$ were resistant. Resistance in Ames 19016 (Va59) was effective in $\mathrm{F}_{1}$ progeny and appeared to be dominant and simply inherited; however, this resistance appeared to be a slow-rusting or incomplete resistance that was effective in adult plants but not in young seedlings. Severity of southern rust was less than $10 \%$ on resistant progeny from crosses with Va59 compared with severity exceeding $70 \%$ on susceptible progeny. Resistance in plant introduction (PI) 186209 (Venezuelan flint) and NSL 75976 (IA DS61) were not effective in $F_{1}$ hybrid combination and, thus, probably have limited value in commercial maize. Resistance in PI 186209 may be conditioned by a single recessive gene and resistance in NSL 75976 may be co-dominant.
\end{abstract}

Additional keywords: Rpp genes

Southern rust, caused by Puccinia polysora Underw., is a troublesome foliar disease of maize (Zea mays L.). The disease develops mainly in tropical and subtropical areas of the world $(8,12,31)$ and is restricted by the temperature sensitivity of the pathogen. In temperate regions, epidemics occur sporadically. The disease spreads rapidly and was destructive throughout Africa following an outbreak in 1949 (12,18). In the United States, southern rust occurs primarily in the lower Mississippi Valley and Texas, but has been found as far north as Massachusetts and Wisconsin (12,17). Epidemics developed in the United States in 1972-74, 1979, and $1981(5,8,11,21,24)$. In the past few years, unusually severe outbreaks of southern rust have been observed in Missouri, Nebraska, and Wisconsin (L. E. Sweets, T. A. Jackson, and W. F. Tracy, personal communications, respectively). The disease also recently has increased in importance in maize-growing regions of northern China (3).

Southern rust can cause substantial yield losses $(3,8,12,18,20)$. $P$. polysora infects leaves, leaf sheaths, and husk leaves and forms uredinia that are smaller but more

Corresponding author: J. K. Pataky

E-mail: j-pataky@uiuc.edu

Accepted for publication: 25 June 2007.

doi:10.1094/PDIS-91-11-1489

(c) 2007 The American Phytopathological Society densely distributed than those of $P$. sorghi Schwein., the casual agent of common corn rust (31). Southern rust becomes progressively more severe as plants mature. Uredinia can become so numerous that leaf and sheath tissues are killed, and plants are prematurely desiccated (20). Melching (12) observed yield reductions of 24 to $37 \%$ following inoculation with $P$. polysora in Maryland. Rodriguez-Anon et al. (20) observed yield reductions of 4, 23, and $45 \%$ when near-isogenic resistant and susceptible hybrids were planted on three sequential dates in Mississippi. Raid et al. (18) observed grain yield reductions of about 18 and 39\% in inoculated field trials in Pennsylvania and Maryland, respectively. Yield losses up to $50 \%$ also have been observed in Africa and China (3,8).

Host resistance is the most efficient means to control southern rust where it occurs frequently. General resistance to $P$. polysora is a component of most tropical maize-breeding programs (4). Most tropical maize has general resistance that reduces severity of infection below economically important levels (25). In an evaluation of maize germplasm adapted for temperate climates, Bailey et al. (1) observed considerable variation for slowrusting resistance (i.e., general resistance) to $P$. polysora among 23 single-cross hybrids and 33 inbred lines. Mo17 was one of five inbred lines with area under the disease progress curve (AUDPC) values that were not significantly different from the inbred with the lowest AUDPC value.
Holland et al. (7) mapped genes from Mo 17 with minor effects on southern rust resistance to chromosome 3 (marker locus umc26) and chromosome 4 (marker locus umc31). Zummo (32) observed differences in sporulation and number, size, and plumpness of uredinia among four maize inbred lines that differed in reaction to $P$. polysora. Scott and Zummo (23) observed fewer, smaller uredinia that sporulated later on hybrids derived from crosses of slow-rusting inbreds compared with susceptible hybrids.

Several sources of simply inherited, specific resistance to $P$. polysora have been identified from different maize lines and populations; and various races of $P$. polysora have been designated. The Rppl and $R p p 2$ genes were identified in Kenya from maize lines AFRO 29 ('Colombia 2') and AFRO 24 ('SLP 20-4A') that originated in Colombia and Mexico, respectively (26). The Rppl gene is dominant and confers complete resistance to race EA1 of $P$. polysora. The Rpp 2 gene conditions an intermediate reaction to races EA1 and EA2 and can be modified to near complete susceptibility by other host genes (8). The Rppl and Rpp2 genes are linked with about $12 \%$ recombination (27). Both genes were ineffective against a third race, EA3, recognized in Kenya in 1961 (28). The Rpp10 and Rppll genes were identified in Kenya from maize lines AFRO 761 ('Andaqui') and AFRO 600 ('Zapalote Chico') that also originated in Colombia and Mexico, respectively (28). The Rpplo gene was dominant and conferred complete resistance to races EA1 and EA3 and, thus, was different from the Rppl gene. The Rppll gene conditioned an incomplete resistance to races EA1 and EA3.

The number of prevalent races of $P$. polysora in North America and elsewhere has not been documented clearly, but diversity may be limited. The sexual stage of $P$. polysora has not been described, and most epidemics are thought to result from initial inocula composed of urediniospores. Nevertheless, races are known to occur. Robert (19) designated 6 new races of $P$. polysora (i.e., PP3 to PP8) in a collection of 11 isolates from North and South America based on the differential response of 11 corn lines which presumably carried the genes Rpp3 to Rpp8. An accession from Argentina, plant introduction (PI) 19802 (4F-345 CN12), was resistant to four of the six new races and to EA1 and EA2. An accession from South Africa, PI 186208 
(Boesman yellow flint), was resistant to EA2 and PP5. Ullstrup (29) identified a single dominant gene, Rpp9, from PI 186208. The Rpp9 gene conferred chlorotic fleck hypersensitive resistance to the prevalent race of $P$. polysora in the U.S. Corn Belt which Ullstrup designated PP9 (i.e., race 9). The Rpp9 gene was linked on chromosome $10 \mathrm{~S}$ about 1.6 centimorgans from the $R p 1 D$ gene which conditions a chlorotic fleck hypersensitive resistance to $P$. sorghi.

The Rpp 9 gene or dominant genes for southern rust resistance that may be closely linked to the Rpp 9 gene have been identified from several sources in addition to PI $186208(3,6,7,10,22,30)$. Futrell et al. (6) identified a single, dominant gene for resistance to $P$. polysora race 9 from an inbred line B1138T which was derived from an open pollinated cultivar, Teko yellow, selected in Natal, South Africa. Futrell et al. (6) did not test whether the gene in B1138T was allelic with the Rpp9 gene. Scott et al. (22) identified single dominant genes for resistance to $P$. polysora in an inbred line Mp78:5273 and in FSHmR, a broad-based population derived from about $40 \%$ tropical and $60 \%$ U.S. germplasm. The resistance genes in Mp78:5273 and FSHmR were allelic with or very closely linked to the Rpp 9 gene. Uhr (30) identified high levels of resistance to $P$. polysora in two temperateadapted, $100 \%$ tropical maize inbreds 1416-1 and 1497-2; and Holland et al. (7) mapped a single locus conditioning southern rust resistance in both inbreds to a region of chromosome $10 \mathrm{~S}$ between restriction fragment length polymorphism loci bnl3.04 and npi285 that flank the Rp1 locus. Evaluations of test crosses of inbreds 1416-1 and 1497-2 with a known source of the Rpp 9 gene were unsuccessful. Jines et al. (10) also mapped a simply inherited, dominant gene conferring southern rust resistance in the inbred line $\mathrm{NC}$ 300 to the short arm of chromosome 10 between the markers umc1380 and bnlg1451 (bins 10.0 and 10.1, respectively). The inbred NC300 and inbreds 1416-1 and 1497-2 (7) may have the same southern rust resistance allele because their pedigrees contain double-cross tropical hybrids PX105A and PX306B (10). A single, dominant, southern rust resistance gene in the Chinese inbred line Qi319, which Chen et al. (3) designated as $R p p Q$, was mapped to the same region of chromosome 10S as the Rp1 and Rpp9 loci. Chen et al. (3) proposed to test this southern rust resistance gene for allelism with the Rpp 9 gene.

A few field corn hybrids with racespecific resistance to southern rust have been sold commercially (7), but none of the $R p p$ genes have been used extensively in field corn or sweet corn developed for the United States. Most of the Rpp genes are not available in adapted temperate germplasm. Of over 600 commerciallyavailable, temperate sweet corn hybrids evaluated for reactions to $P$. polysora, only two, Calvary and Suregold, have chloroticfleck-resistant reactions $(14,16)$. Only 18 of 379 sweet corn hybrids evaluated for reactions to $P$. polysora in 2006 had moderate levels of general resistance (16). So et al. (25) observed that essentially all temperate sweet corn hybrids were highly susceptible to $P$. polysora under environmental conditions conducive to southern rust epidemics in Hawaii. Additional resistance to $P$. polysora is necessary if temperate-based sweet corn germplasm is to be grown in subtropical climates where $P$. polysora is endemic or if $P$. polysora increases in prevalence in temperate regions in response to warmer climates.

The objectives of this study were to screen maize accessions for potential sources of resistance to $P$. polysora, determine whether resistance to $P$. polysora in resistant accessions was inherited simply, and determine whether genes conferring resistance in these accessions were allelic with the Rpp9 gene.

\section{MATERIALS AND METHODS}

Accessions evaluated for resistance to $\boldsymbol{P}$. polysora race 9. Two thousand maize accessions were obtained from the North Central Regional Plant Introduction Station (NCRPIS), Ames, IA. Accessions were selected by Mark Millard, NCRPIS maize curator, as representative of maize germplasm adapted for temperate climates from all regions of the world and representative of sweet corn and field corn germplasm from the United States. The 2,000 accessions were planted 22 May 1997 at the University of Illinois South Farm, Urbana. The trial included single rows of accessions with approximately 15 plants per accession. Rows were spaced $0.76 \mathrm{~m}$ apart. Reactions to $P$. polysora could not be assessed for 110 accessions due to poor germination. Of the 1,890 accessions evaluated, 889 were collected originally from the United States and 1,001 were collected from at least 48 other countries (13).

Plants at the five- to eight-leaf stage were inoculated with $P$. polysora race 9 on 30 June and 7 July. Urediniospores were obtained from J. M. Perkins (Dekalb Genetics, Dekalb, IL) and maintained on susceptible plants grown in a greenhouse. Inoculum for this and other field trials was increased on about 600 field-grown plants of sweet corn hybrids that carried the Rpl$D$ gene in order to prevent contamination of inoculum with $P$. sorghi. About 100 severely infected leaves with 60 to $80 \%$ of the upper leaf surface covered with profusely sporulating uredinia were washed in 4 liters of water and $10 \mathrm{ml}$ of Tween-20 (polyoxyethylene-20) to produce a concentrated suspension of urediniospores. Urediniospore suspensions were diluted 10:1 with water. About $5 \mathrm{ml}$ of diluted inoculum was sprayed directly into the leaf whorls of plants. Reactions of plants were rated on a row basis on 25 to 26 August using a 0 -to3 scale, where $0=$ chlorotic flecks with no uredinia, $1=$ partially resistant with a few small uredinia, $2=$ moderately susceptible with moderate numbers of uredinia, and 3 $=$ fully susceptible with an abundance of uredinia. Some rows were given two ratings (e.g., 0/1, 1/2) if all plants did not appear to have the same phenotype. Accessions with ratings of 0 and 1 were reevaluated in 1998 in a trial smaller than but similar to the trial in 1997. Three inbred lines, B37, Oh43, and W64a, into which the Rpp9 gene had been backcrossed were obtained from D. R. Smith (Dekalb Genetics) and included as resistant checks in the 1998 trial.

Preliminary tests of allelism and inheritance. Uredinia were not observed on five accessions-Ames 19016 (Va59), NSL 75976 (IA DS61), PI 186209 (Venezuela yellow flint), PI 186215 (inbred 2687 from Argentina), and PI 198905 (4F374-GE 3) - and the inbred lines with the Rpp 9 gene. In order to determine whether genes conferring resistance in these accessions were allelic or closely linked to the Rpp9 gene, the five accessions were crossed with one or more of the inbred lines carrying the Rpp9 gene, B37Rpp9, Oh43Rpp9, and W64aRpp9. The resulting $\mathrm{F}_{1}$ crosses then were test crossed with susceptible sweet corn inbred lines (M32, M12, or Cr44). Progeny of test crosses were screened for reactions to $P$. polysora in field trials at the University of Illinois South Farm in 2000 and 2001. Resistant controls were $\mathrm{F}_{1}$ crosses of inbred lines with the Rpp9 gene (i.e, W64aRpp9 $\times$ Oh43Rpp 9 and W64aRpp $9 \times \mathrm{B} 37 R p p 9)$. The sweet corn hybrid 'Bonus' was the susceptible control. Each trial included two replicates of test crosses of the five accessions (i.e., accession $\times R p p 9) \times$ susceptible inbred, the resistant controls, and the susceptible control. The experimental design was a randomized complete block. Each replicate included different numbers of rows (ranging from 8 to 40) of each test cross depending on availability of seed, 4 rows of each resistant control, and 8 rows of the susceptible control. Each row was $3.8 \mathrm{~m}$ long with approximately 12 plants per row. Rows were spaced $0.76 \mathrm{~m}$ apart. Trials were planted 20 May 2000 and 10 May 2001. In both years, inoculum was produced as described above. Plants were inoculated between the seven-leaf to row tassel (i.e., VT) growth stages on 6, 8, 11, and 13 July 2000 and 26 June and 7, 11, and 16 July 2001. Individual plants were rated for the presence (susceptible) or absence (resistant) of uredinia near the end of August. Segregation of progeny from testcrosses were tested by $\chi^{2}$ for goodness of fit to $1: 0,3: 1$, or $1: 1$ ratios (resistant:susceptible [R:S]) which would be 
expected if resistance in an accession was allelic with the Rpp 9 gene, dominant and independent from the $R p p 9$ gene, or recessive and independent from the Rpp9 gene, respectively.

Inheritance of resistance in accession Ames 19016 (Va59) also was evaluated in preliminary field and greenhouse trials in 2001. The accession $\left(P_{R}\right)$ was crossed with susceptible sweet corn inbred lines $\left(\mathrm{P}_{\mathrm{S}}\right)$, M32, M12, or $\mathrm{Cr} 44$, to produce the $\mathrm{F}_{1}$ generation. $\mathrm{F}_{2}, \mathrm{BC}_{\mathrm{R}}$, and $\mathrm{BC}_{\mathrm{S}}$ generations were created by self pollinating the $F_{1}$ or by backcrossing the $F_{1}$ to Va59 or to a susceptible sweet corn inbred, respectively. The field trial included two replicates of a susceptible control, $P_{R}$, and the $F_{1}, F_{2}$, $\mathrm{BC}_{\mathrm{R}}$, and $\mathrm{BC}_{\mathrm{S}}$ generations. The number of rows of each generation varied among generations depending on availability of seed. The experimental design was a randomized complete block. Field trials were planted, inoculated, and rated as described previously for the 2001 preliminary test of allelism.

The same generations also were evaluated in four greenhouse trials. In two of the greenhouse trials, plants were inoculated at the V2 to V3 stage as soon as leaf whorls were large enough to retain urediniospore suspensions. In the other two greenhouse trials, plants were inoculated after plants reached the six- or seven-leaf stage. Each greenhouse trial included two replicates of the generations evaluated in the field trials. The experimental design was a randomized complete block. The first two trials included $3,3,9,6,12$, and 9 rows of the susceptible control, $\mathrm{P}_{\mathrm{R}}, \mathrm{F}_{1}, \mathrm{~F}_{2}, \mathrm{BC}_{\mathrm{R}}$, and $\mathrm{BC}_{\mathrm{S}}$ generations, respectively. The second two trials included three rows of each treatment. Plants were grown in 30-by-60by-7-cm flats with six rows per flat and approximately eight plants per row. The pathogen was maintained on plants of the sweet corn hybrid Bonus. In each of the four trials, plants were inoculated four times within a week. Inoculum was produced and plants were inoculated similar to the previous description except that the volume of inocula and the amount of inocula retained in plant whorls was considerably less than in field trials. Plants were rated for the presence (susceptible) or absence (resistant) of uredinia about 21 days after the last inoculation. Segregation of progeny was tested by $\chi^{2}$ for goodness of fit for ratios that would be expected if resistance in Va59 was inherited as a dominant gene.

Inheritance of resistance and tests of allelism with the $\boldsymbol{R p p} \boldsymbol{9}$ gene. To study the inheritance of resistance, four sources of resistance-Ames 19016 (Va59), NSL 75976 (IA DS61), PI 186209 (Venezuela yellow flint), and PI 186215 (inbred 2-687 from Argentina)—were crossed with a susceptible sweet corn inbred line (M32, $\mathrm{M} 12$, or $\mathrm{Cr} 44$ ) to produce the $\mathrm{F}_{1}$ generation. $\mathrm{F}_{2}, \mathrm{BC}_{\mathrm{R}}$, and $\mathrm{BC}_{\mathrm{S}}$ generations were created by self pollinating the $F_{1}$ or by backcrossing the $F_{1}$ to the $P_{R}$ (accession) or to $\mathrm{P}_{\mathrm{S}}$ (a susceptible sweet corn inbred, M32, M12, or Cr44), respectively. To test for allelism with the Rpp 9 gene, each source of resistance was crossed with a field corn inbred line known to have the Rpp9 gene (B37Rpp9, Oh43Rpp9, or W64aRpp9) to produce an $\mathrm{F}_{1}$. Segregating generations were developed by selfpollinating $F_{1}$ progeny to produce the $F_{2}$ generation and by test crossing $F_{1}$ progeny with a susceptible sweet corn inbred $\left(\mathrm{P}_{\mathrm{S}}\right)$.

Phenotypes were evaluated in two trials at the University of Illinois South Farms in 2005. The two trials were planted 17 May and 13 June. Each trial included two replicates of generations from crosses with each source of resistance. Each row was $3.8 \mathrm{~m}$ long with about 20 plants per row. Rows were spaced $0.76 \mathrm{~m}$ apart. Each trial included 416 rows. Each replicate was blocked by sources of resistance and generations. The number of rows of each generation varied among populations due to availability of seed; however, each replicate usually contained one to three rows of a susceptible control, $P_{R}$, both $F_{1}$ generations $\left(\mathrm{P}_{\mathrm{R}} \times \mathrm{P}_{\mathrm{S}}\right.$ and $\left.\mathrm{P}_{\mathrm{R}} \times R p p 9\right), \mathrm{BC}_{\mathrm{R}}$, and B37Rpp 9, Oh43Rpp9, or W64aRpp9. Each replicate also included 7 to 15 rows of $\mathrm{BC}_{\mathrm{S}}, \mathrm{F}_{2},\left(\mathrm{P}_{\mathrm{R}} \times R p p 9\right) \times \mathrm{P}_{\mathrm{S}}$, and $\left(\mathrm{P}_{\mathrm{R}} \times\right.$ Rpp9) $\mathrm{F}_{2}$. Plants in the trial planted on 17 May were inoculated from the seven-leaf to row tassel (VT) growth stages on 6, 7, 9, 12 , and 26 July. Plants in the trial planted on 13 June were inoculated from the fourto eight-leaf growth stages on $6,7,9,12$, 20 , and 25 July. Inoculum was produced and plants were inoculated as described previously. If tassels had emerged, urediniospore suspensions were sprayed behind leaf sheaths. Phenotypes were scored at least 20 days after the final inoculation. Each plant was placed in one of three categories: $\mathrm{S}=$ susceptible phenotypes with numerous, profusely sporulating uredinia (leaf area infected > 25\%); I = intermediate phenotypes with a few sporulating uredia (leaf area infected $<25 \%$ ); and $\mathrm{R}=$ resistant phenotypes without sporulating uredia. Intermediate phenotypes were grouped with susceptible phenotypes except for crosses with Ames 19016 (Va59), for which severity was less than $10 \%$ on plants placed in the intermediate category; thus, they were grouped with resistant phenotypes.

Segregation was analyzed by $\chi^{2}$ goodness-of-fit tests. If a single, dominant gene conditioned resistance in any of the accessions, the expected ratios of $\mathrm{R}: \mathrm{S}$ plants would be $1: 0,1: 1$, and $3: 1$ in the $\mathrm{BC}_{\mathrm{R}}$, $\mathrm{BC}_{\mathrm{S}}$, and $\mathrm{F}_{2}$ generation, respectively. If a single, recessive gene conditioned resistance in any of the accessions, the expected ratios of $\mathrm{R}: \mathrm{S}$ plants would be $1: 1$, $0: 1$, and $1: 3$ in the $\mathrm{BC}_{\mathrm{R}}, \mathrm{BC}_{\mathrm{S}}$ and $\mathrm{F}_{2}$ generation, respectively. If the resistance in each of the four sources was allelic to the
Rpp9 gene, all $\mathrm{F}_{2}$ and test cross progeny from crosses with $R p p 9$ would be resistant. If a single, dominant gene independent from the $R p p 9$ gene conditioned resistance in any of the accessions, $\mathrm{F}_{2}$ and test cross progeny from crosses with Rpp 9 would segregate $3: 1$ and $15: 1$, respectively. If a single, recessive gene independent from the Rpp 9 gene conditioned resistance in any of the accessions, $F_{2}$ and test cross progeny from crosses with Rpp 9 would segregate $13: 3$ and $1: 1$, respectively.

\section{RESULTS}

Sources of resistance in maize accessions. About $97 \%$ of the 1,890 accessions evaluated were susceptible to $P$. polysora. Of the 55 accessions that were rated 0.5 to 1 and appeared to have some partial resistance to southern rust, 30 were collected from South America, 12 from the United States, and 7 from Africa (Table 1). No attempt was made to separate levels of resistance among these lines or to evaluate resistance contributed by these lines to $F_{1}$ hybrids when crossed with a susceptible tester.

Uredinia were not observed on six accessions which had a chlorotic-fleckresistant phenotype similar to the resistance conditioned by the Rpp 9 gene. These included Ames 19016 (Va59), NSL 75976 (IA DS61), PI 186209 (Venezuela yellow flint), PI 186215 (Argentine inbred 2-687), PI 198905 (4F-374 GE 3), and PI 186191 (Uruguay inbred 627). All of these except PI 186191 were crossed with inbred lines carrying the Rpp9 gene. All but PI 186191 and PI 198905 also were crossed with susceptible sweet corn inbreds.

Preliminary tests of allelism and inheritance. Based on segregation of progeny from testcrosses (i.e., [accessions $x$ Rpp9 line] $\times \mathrm{P}_{\mathrm{S}}$ ), the resistance in PI 186215 appeared to be allelic with the Rpp9 gene; Ames 19016 appeared to have dominant resistance that was independent of the Rpp9 gene; and NSL 75976, PI 186209, and PI 198905 appeared to be susceptible or have resistance that was recessive (Table 2). All but 3 of 1,707 test cross progeny from (inbred 2-687 $\times R p p 9$ line) $\times \mathrm{P}_{\mathrm{S}}$ were resistant. Therefore, resistance to $P$. polysora in inbred 2-687 appeared to be allelic with or very closely linked to the Rpp 9 gene. Testcross progeny from $($ Va59 $\times R p p 9$ line $) \times \mathrm{P}_{\mathrm{S}}$ segregated $823: 300$ (R:S) which was not significantly different from a ratio of $3: 1(P=0.185)$. A $3: 1$ ratio of segregation would occur if resistance in Va59 was dominant and independent of the Rpp 9 gene. Test cross progeny from (PI $186209 \times R p p 9$ line $) \times \mathrm{P}_{\mathrm{S}}$ and (PI $198905 \times R p p 9$ line $) \times \mathrm{P}_{\mathrm{S}}$ segregated in a ratio that was not significantly different from $1: 1(P=0.406$ and 0.085 , respectively). Segregation from the testcross $($ NSL $75976 \times R p p 9$ line $) \times \mathrm{P}_{\mathrm{S}}$ was slightly different from $1: 1$ due to more resistant than susceptible progeny. Segregation of $1: 1$ would be expected in test cross prog- 
eny if resistance was inherited only from the Rpp9 gene; thus, these accessions likely have resistance that is recessive and not expressed in test cross progeny.

Resistance in Va59 appeared to be conditioned by a single, dominant gene based on field trials in 2001; however, this resistance was not expressed in subsequent greenhouse trials of seedlings (Table 3 ). All but four $F_{1}$ progeny and all but one $\mathrm{BC}_{\mathrm{R}}$ progeny were resistant in field trials, as expected. Segregation of $\mathrm{BC}_{\mathrm{S}}$ and $\mathrm{F}_{2}$

Table 1. Maize accessions with resistance to Puccinia polysora race 9 in field trials in Urbana, IL in 1997 and 1998

\begin{tabular}{|c|c|c|}
\hline Rating and accession ${ }^{a}$ & Source & Accession name \\
\hline \multicolumn{3}{|l|}{ Accessions rated 0} \\
\hline Ames 19016 & Virginia & Va59 \\
\hline NSL 75976 & Iowa & IA DS61 \\
\hline PI 186209 & Venezuela & Yellow Flint \\
\hline PI 186215 & Argentina & Inbred 2-687 \\
\hline PI 198905 & Argentina & 4F-374 GE 3 \\
\hline PI 186191 & Uruguay & Inbred 627 \\
\hline \multicolumn{3}{|l|}{ Accessions rated 0.5} \\
\hline PI 484024 & United States & Puerto Rico 13 \\
\hline PI 515053 & Peru & Loreto 9 \\
\hline PI 515055 & Peru & Loreto 11 \\
\hline PI 515097 & Peru & San Martin 126 \\
\hline PI 553058 & Iowa & OC5 \\
\hline PI 558524 & Missouri & Mo6 \\
\hline PI 596502 & Iowa & OC15 \\
\hline \multicolumn{3}{|l|}{ Accessions rated 1} \\
\hline Ames 13103 & Mississippi & Kyles Long Ear \\
\hline Ames 19004 & Virginia & Va21A \\
\hline Ames 19006 & Virginia & $\mathrm{Va} 22 \mathrm{~B}$ \\
\hline Ames 19284 & Iowa & $\mathrm{C} 103$ \\
\hline Ames 19467 & Mexico & Guerrero 3 \\
\hline NSL 174429 & California & INB 101LFY \\
\hline PI 162703 & Argentina & Maiz Amarillo Klein \\
\hline PI 162926 & Paraguay & Mkt., Asuncion \\
\hline PI 171915 & Turkey & Niksar, Tokat \\
\hline PI 177651 & Syria & Arnet, Damascus \\
\hline PI 186182 & Uruguay & Inbred 378 \\
\hline PI 186230 & Uruguay & Inbred 334 \\
\hline PI 194047 & Ethiopia & No. 8815 \\
\hline PI 194387 & Ethiopia & No. 9179 \\
\hline PI 194388 & Ethiopia & No. 9180 \\
\hline PI 197503 & Ethiopia & Various markets \\
\hline PI 198888 & Argentina & $4 \mathrm{~F}-35 \mathrm{BK}$ \\
\hline PI 198893 & Argentina & $4 \mathrm{~F}-240 \mathrm{BX} 16$ \\
\hline PI 200183 & Israel & No. 162 \\
\hline PI 200304 & Yugoslavia & No. 1122 \\
\hline PI 200307 & Yugoslavia & No. 1126 \\
\hline PI 217407 & Iowa & Ladyfinger \\
\hline PI 221750 & South Africa & E292 \\
\hline PI 221806 & South Africa & A256-1 \\
\hline PI 221821 & South Africa & E680 \\
\hline PI 240326 & Bolivia & No. 9 \\
\hline PI 368830 & Yugoslavia & Pukanki Zolti 1294 \\
\hline PI 443762 & Columbia & Antioquia 308 \\
\hline PI 443803 & Columbia & Antioquia 373 \\
\hline PI 443806 & Columbia & Antioquia 377 \\
\hline PI 443986 & Columbia & Atlatnico 308 \\
\hline PI 444018 & Columbia & Bolivar 308 \\
\hline PI 444029 & Columbia & Bolivar 326 \\
\hline PI 444831 & Columbia & Huil 1351 \\
\hline PI 444888 & Columbia & Magdelena 310 \\
\hline PI 444929 & Columbia & Magdelena 362 \\
\hline PI 445526 & Columbia & Tolima 403 \\
\hline PI 445578 & Columbia & Valle 343 \\
\hline PI 450051 & Brazil & Comum 094-R2 \\
\hline PI 515042 & Peru & Lima 86 \\
\hline PI 515052 & Peru & Loreto 8 \\
\hline PI 515063 & Peru & San Martin 7 \\
\hline PI 515064 & Peru & San Martin 9 \\
\hline PI 558532 & Missouri & Mo17 \\
\hline PI 571725 & Peru & San Martin 111 \\
\hline PI 576309 & Columbia & Narino 628 \\
\hline PI 577828 & Bolivia & BOZM 1155 \\
\hline PI 587136 & Kentucky & Ky228 \\
\hline
\end{tabular}

a Rating: $0=$ chlorotic-fleck reaction, no uredinia; 0.5 = very few, very small uredinia or segregating for chlorotic fleck reactions; and 1 = few, small uredinia, mostly on lower leaves. progeny in field trials was not significantly different from ratios of $1: 1$ and $3: 1$, respectively ( $P=0.699$ and 0.388 , respectively). In two greenhouse trials inoculated at a seedling stage (i.e., prior to four-leaf stage), 93 of $96 \mathrm{P}_{\mathrm{R}}$ plants, 226 of $238 \mathrm{~F}_{1}$ plants, and 138 of $140 \mathrm{BC}_{\mathrm{R}}$ plants were susceptible. Uredinia were not observed on approximately $10 \%$ (7 of 73) of the susceptible control plants which apparently escaped infection. Likewise, the percentage of resistant progeny was not significantly greater than $10 \%$ for any of the other generations evaluated in these two trials. Therefore, all resistant plants likely were escapes, and all plants in the trial were susceptible. In the two greenhouse trials inoculated after plants had at least six leaves, only one susceptible control plant escaped infection. All 70 plants of Va59 were resistant, but 18 of $69 \mathrm{~F}_{1}$ plants and 11 of $68 \mathrm{BC}_{\mathrm{R}}$ plants were susceptible. Progeny of the $\mathrm{BC}_{\mathrm{S}}$ and $\mathrm{F}_{2}$ generations segregated in ratios that were similar $(P=$ 0.017 and 0.093$)$ to $1: 1$ and $3: 1$, respectively.

Inheritance of resistance and tests of allelism with the Rpp9 gene. Southern rust was more severe in the late-planted trials than in the early-planted trials in 2005, probably due to the growth stage at which plants initially were inoculated. In rows of susceptible check plants, severity exceeded $40 \%$ leaf area infected in the early-planted trials and $70 \%$ in the lateplanted trials. All plants of the four PI accessions and the three inbreds with the Rpp9 gene were resistant except for four plants of NSL 75976 (IA DS61), which may have been due to a planting error (Tables 4 and 5). Inheritance of resistance and allelism with the Rpp 9 gene differed among the four PI accessions.

PI 186215 (Argentine inbred 2-687). Segregation of progeny in the $\mathrm{F}_{2}$ and $\mathrm{BC}_{\mathrm{S}}$ generations of the inheritance study was not significantly different $(P>0.35)$ from the ratios expected if resistance in PI 1862215 (inbred 2-687) was conditioned by a single, dominant gene (Table 4 ). The resistant reaction was a hypersensitive, chlorotic-fleck response to $P$. polysora. There were no intermediate responses. All 651 testcross progeny and $483 \mathrm{~F}_{2}$ progeny in the test of allelism with the Rpp 9 gene were resistant (Table 5). The resistance in PI 186215 appears to be allelic with the Rpp9 gene. In all trials $(2000,2001$, and 2005 ) only 3 of 2,357 test cross progeny were susceptible. These three plants probably represent planting or pollination errors.

Ames 19016 (Va59). Segregation of $F_{2}$ progeny of Ames $19016 \times \mathrm{P}_{\mathrm{S}}$ in the earlyplanted inheritance trial and segregation of $\mathrm{BC}_{\mathrm{S}}$ progeny in both inheritance trials were not significantly different $(P>0.01)$ from those expected if resistance was conferred by a single, dominant gene (Table 4). However, $F_{2}$ progeny from the late- 
planted trial did not fit a 3:1 ratio because of a larger number of susceptible plants than expected. Also, about $10 \%$ of the progeny in the $F_{1}$ and $B_{R}$ generations were susceptible in the late-planted trial, even though all of these plants should have been resistant. The resistance conferred by Ames 19016 was not as complete as that conferred by the Rpp 9 gene. $\mathrm{F}_{1}$ progeny and resistant progeny in segregating generations often had an intermediate reaction with less than $10 \%$ leaf area infected. Possibly, some plants with intermediate and susceptible reactions were misclassified, particularly in the late-planted trial, in which southern rust was more severe. Alternatively, the resistance of Ames 19016 may be related to plant growth stage (i.e., adult-plant resistance) and a greater number of plants inoculated as seedlings in the late-planted trial were susceptible.

Based on the test of allelism, the resistance in Ames 19016 appears to be different than that conferred by the Rpp 9 gene (Table 5). Segregation of test cross and $\mathrm{F}_{2}$ progeny in the early-planted trial support the hypothesis that resistance in Ames 19016 is conferred by a single, dominant gene that is independent of the Rpp 9 gene. In the late-planted allelism trial, the number of susceptible plants among test cross and $F_{2}$ progeny was larger than expected, which was similar to reactions of $F_{2}$ progeny in the late-planted inheritance trial.

PI 186209 (Venezuelan flint). Segregation of $\mathrm{F}_{2}$ progeny in the late-planted inheritance trial and $\mathrm{BC}_{\mathrm{R}}$ progeny in both inheritance trials was not significantly different $(P>0.01)$ from expected if resistance in PI 186209 was conditioned by a single, recessive gene (Table 4). The number of resistant plants among $F_{2}$ progeny in the early-planted trial was larger than expected based on a single, recessive gene hypothesis. The resistant reaction of PI 186209 was similar to the hypersensitive, chlorotic-fleck reaction of the Rpp 9 gene. Segregation of test cross progeny in both allelism trials fit a $1: 1$ ratio $(P=0.96$ and 0.28 , respectively), which would be expected if resistance was conferred only by the Rpp 9 gene and a recessive gene from PI 186209 was not expressed (Table 5). Segregation in the $F_{2}$ generation fit a 13:3 ratio $(P=0.03$ and 0.04$)$, which would be expected if PI 186209 carried a recessive gene for a chlorotic-fleck reaction; however, the segregation in the $F_{2}$ generation of both allelism trials more closely fit $(P=$ 0.32 and 0.44 ) a $3: 1$ ratio that would be expected if resistance was conferred only by the Rpp 9 gene.

NSL 75976 (IA DS61). Although NSL 75976 appeared to be resistant in initial screening of germplasm and in the inheritance trials, few of the progeny from crosses with NSL 75976 were resistant (Table 4). Only $1 \mathrm{~F}_{2}$ progeny of NSL $75976 \times \mathrm{P}_{\mathrm{S}}$ was resistant in the late- planted trial and only 11 of 374 progeny were resistant in the early-planted trial. Likewise, none of the $\mathrm{BC}_{\mathrm{R}}$ progeny were resistant in the late-planted trial and only 7 of 52 progeny were resistant in the early-planted trial. Possibly, resistance in NSL 75976 is co-dominant or polygenic. If this resistance is co-dominant, progeny with intermediate phenotypes may have been classified as susceptible based on our method of scoring rust reactions. Segregation of test cross progeny and $\mathrm{F}_{2}$ progeny in the late-planted allelism trial were not significantly different $(P>0.28)$ from $1: 1$ and $3: 1$, which would be expected if resistance in these generations was inherited solely from the Rpp 9 gene (Table 5).

\section{DISCUSSION}

A number of potential sources of general and specific resistance to $P$. polysora were identified from 1,890 PI accessions that were representative of temperate-adapted maize germplasm collected throughout the world. The number of uredinia was reduced and southern rust was less severe on 55 accessions that appeared to have general resistance. Many of those accessions were from South America. Quantitative trait loci with minor effects on southern rust resistance have been mapped to chromosomes 3 and 4 in one of these sources, Mo17 (7).

Uredinia did not form on six accessions that presumably carried specific resistance to $P$. polysora race 9 . Resistance to $P$. poly-

Table 2. Segregation of progeny from testcrosses of plant introduction accessions that were potential sources of resistance to Puccinia polysora and field corn inbred lines carrying the Rpp 9 gene

\begin{tabular}{|c|c|c|c|c|c|}
\hline \multirow{2}{*}{$\begin{array}{l}\text { Crosses and controls tested } \\
\text { and PI accession sources of resistance }\end{array}$} & \multirow{2}{*}{$\begin{array}{c}\begin{array}{c}\text { Hypothesized } \\
\text { ratio }^{\mathrm{a}}\end{array} \\
\text { R:S }\end{array}$} & \multicolumn{2}{|c|}{$\begin{array}{c}\text { Reaction of } \\
\text { progeny }\end{array}$} & \multirow[b]{2}{*}{$\chi^{2 b}$} & \multirow[b]{2}{*}{$P^{c}$} \\
\hline & & $\mathbf{R}$ & $\mathbf{S}$ & & \\
\hline \multicolumn{6}{|c|}{$($ Accession $\times \operatorname{Rpp} 9$ line $) \times$ susceptible tester $(\mathrm{M} 32, \mathrm{M} 12$, or $\mathrm{Cr} 44)$} \\
\hline PI 186215 (Inbred 2-687) & $1: 0$ & 1,703 & 3 & & \\
\hline Ames $19016(\mathrm{Va59})$ & $3: 1$ & 823 & 300 & 1.76 & 0.185 \\
\hline NSL 75976 (IA DS 61) & $1: 1$ & 478 & 399 & 7.12 & 0.008 \\
\hline PI 186209 (Yellow Flint) & $1: 1$ & 135 & 149 & 0.69 & 0.406 \\
\hline PI 198905 (4F-374 GE 3) & $1: 1$ & 146 & 177 & 2.98 & 0.085 \\
\hline \multicolumn{6}{|l|}{ Controls: $R p p 9$-resistant and susceptible } \\
\hline W64aRpp $9 \times \mathrm{Oh} 43 R p p 9$ & & 156 & 0 & & \\
\hline $\mathrm{W} 64 \mathrm{a} R p p 9 \times \mathrm{B} 37 R p p 9$ & & 153 & 0 & & \\
\hline Bonus (susceptible check) & & 3 & 300 & & \\
\hline
\end{tabular}

a Hypothesized ratios for testcrosses: 1:0, allelic or very closely linked to Rpp9; 3:1, single, dominant gene independent of $\operatorname{Rpp} 9 ; 1: 1$, no resistance or recessive resistance.

b Chi-square value from a goodness-of-fit test based on the hypothesized ratio.

c Probability associated with the chi-square value from the goodness-of-fit test.

Table 3. Segregation analysis for chlorotic fleck resistance to Puccinia polysora among crosses of Ames 19016 (Va59) and susceptible sweet corn inbreds evaluated in field and greenhouse trials in 2001

\begin{tabular}{|c|c|c|c|c|c|}
\hline \multirow[b]{2}{*}{ Trials and generations } & \multirow{2}{*}{$\begin{array}{c}\begin{array}{c}\text { Hypothesized } \\
\text { ratio }^{\text {a }}\end{array} \\
\text { R:S } \\
\end{array}$} & \multicolumn{2}{|c|}{$\begin{array}{c}\text { Reaction of } \\
\text { progeny }\end{array}$} & \multirow[b]{2}{*}{$\chi^{2 \mathrm{~b}}$} & \multirow[b]{2}{*}{$P^{c}$} \\
\hline & & $\mathbf{R}$ & $\mathbf{S}$ & & \\
\hline \multicolumn{6}{|l|}{ Field trials } \\
\hline Bonus (susceptible check) & $0: 1$ & 0 & 42 & & \\
\hline $\mathrm{P}_{\mathrm{R}}$ & $1: 0$ & 22 & 0 & & \\
\hline $\mathrm{F}_{1}$ & $1: 0$ & 69 & 4 & & \\
\hline $\mathrm{BC}_{\mathrm{R}}$ & $1: 0$ & 102 & 1 & & \\
\hline $\mathrm{BC}_{\mathrm{S}}$ & $1: 1$ & 86 & 81 & 0.15 & 0.699 \\
\hline $\mathrm{F}_{2}$ & $3: 1$ & 101 & 28 & 0.75 & 0.388 \\
\hline \multicolumn{6}{|l|}{ Greenhouse trials: $<4$ leaves $^{\mathrm{d}}$} \\
\hline Bonus (susceptible check) & $0: 1$ & 7 & 67 & & \\
\hline $\mathrm{P}_{\mathrm{R}}$ & $1: 0$ & 3 & 93 & & \\
\hline $\mathrm{F}_{1}$ & $1: 0$ & 12 & 226 & & \\
\hline $\mathrm{BC}_{\mathrm{R}}$ & $1: 0$ & 2 & 138 & & \\
\hline $\mathrm{BC}_{\mathrm{S}}$ & $1: 1$ & 35 & 315 & 225 & $<0.001$ \\
\hline $\mathrm{F}_{2}$ & $3: 1$ & 2 & 207 & 611 & $<0.001$ \\
\hline \multicolumn{6}{|l|}{ Greenhouse trials: $>6$ leaves $^{\mathrm{d}}$} \\
\hline Bonus (susceptible check) & $0: 1$ & 1 & 53 & & \\
\hline $\mathrm{P}_{\mathrm{R}}$ & $1: 0$ & 70 & 0 & & \\
\hline $\mathrm{F}_{1}$ & $1: 0$ & 51 & 18 & & \\
\hline $\mathrm{BC}_{\mathrm{R}}$ & $1: 0$ & 57 & 11 & & \\
\hline $\mathrm{BC}_{\mathrm{S}}$ & $1: 1$ & 45 & 25 & 5.71 & 0.017 \\
\hline $\mathrm{F}_{2}$ & $3: 1$ & 57 & 11 & 2.82 & 0.093 \\
\hline
\end{tabular}


Table 4. Analysis of segregation to determine inheritance of resistance to Puccinia polysora in four plant introduction accessions in early and late planted field trials in 2005

\begin{tabular}{|c|c|c|c|c|c|c|c|c|c|}
\hline \multirow{3}{*}{$\begin{array}{l}\text { PI source of resistance, } \\
\text { trials, and generations }\end{array}$} & \multirow{3}{*}{$\begin{array}{c}\begin{array}{c}\text { Hypothesized } \\
\text { ratio }^{c}\end{array} \\
\text { R:S }\end{array}$} & \multicolumn{4}{|c|}{ Early planted trial ${ }^{\mathbf{a}}$} & \multicolumn{4}{|c|}{ Late planted trial ${ }^{b}$} \\
\hline & & \multicolumn{2}{|c|}{ Reaction of progeny } & \multirow[b]{2}{*}{$\chi^{2 \mathrm{~d}}$} & \multirow[b]{2}{*}{$P^{\mathrm{e}}$} & \multicolumn{2}{|c|}{ Reaction of progeny } & \multirow[b]{2}{*}{$\chi^{2 \mathrm{~d}}$} & \multirow[b]{2}{*}{$P^{\mathrm{e}}$} \\
\hline & & $\mathbf{R}$ & $\mathbf{S}$ & & & $\mathbf{R}$ & $\mathbf{S}$ & & \\
\hline \multicolumn{10}{|c|}{ PI 186215 (Argentine inbred 2-687) } \\
\hline Bonus (susceptible check) & $0: 1$ & 0 & 23 & & & 0 & 32 & & \\
\hline $\mathrm{P}_{\mathrm{R}}(\mathrm{PI} 186215)$ & $1: 0$ & 12 & 0 & & & $\ldots$ & $\ldots$ & & \\
\hline $\mathrm{F}_{1}$ & $1: 0$ & 23 & 3 & & & 27 & 0 & & \\
\hline $\mathrm{BC}_{\mathrm{S}}$ & $1: 1$ & 115 & 121 & 0.15 & 0.696 & 124 & 110 & 0.84 & 0.36 \\
\hline $\mathrm{F}_{2}$ & $3: 1$ & 151 & 48 & 0.08 & 0.775 & 156 & 45 & 0.73 & 0.394 \\
\hline \multicolumn{10}{|l|}{ Ames $19016(\mathrm{Va} 59)$} \\
\hline Bonus (susceptible check) & $0: 1$ & 0 & 53 & & & 0 & 85 & & \\
\hline $\mathrm{P}_{\mathrm{R}}($ Ames 19016$)$ & $1: 0$ & 117 & 0 & & & 107 & 0 & & \\
\hline $\mathrm{F}_{1}$ & $1: 0$ & 111 & 1 & & & 117 & 12 & & \\
\hline $\mathrm{BC}_{\mathrm{R}}$ & $1: 0$ & 56 & 2 & & & 61 & 6 & & \\
\hline $\mathrm{BC}_{\mathrm{S}}$ & $1: 1$ & 67 & 89 & 3.1 & 0.078 & 92 & 125 & 5.0 & 0.025 \\
\hline $\mathrm{F}_{2}$ & $3: 1$ & 204 & 80 & 1.52 & 0.217 & 183 & 167 & 96.3 & $<0.001$ \\
\hline \multicolumn{10}{|l|}{ PI 186209 (Venezuelan flint) } \\
\hline Bonus (susceptible check) & $0: 1$ & 0 & 70 & & & 0 & 62 & & \\
\hline $\mathrm{P}_{\mathrm{R}}(\mathrm{PI} 186209)$ & $1: 0$ & 7 & 0 & & & $\ldots$ & $\ldots$ & & \\
\hline $\mathrm{BC}_{\mathrm{R}}$ & $1: 1$ & 13 & 26 & 4.3 & 0.037 & 10 & 24 & 5.8 & 0.016 \\
\hline $\mathrm{BC}_{\mathrm{S}}$ & $0: 1$ & 10 & 107 & & & 3 & 110 & & \\
\hline $\mathrm{F}_{2}$ & $1: 3$ & 109 & 190 & 20.9 & $<0.001$ & 64 & 184 & 0.1 & 0.077 \\
\hline \multicolumn{10}{|l|}{ NSL 75976 (IA DS61) } \\
\hline Bonus (susceptible check) & $0: 1$ & 0 & 48 & & & 0 & 67 & & \\
\hline $\mathrm{P}_{\mathrm{R}}(\mathrm{NSL} 75976)$ & $1: 0$ & 20 & 4 & & & 18 & 0 & & \\
\hline $\mathrm{F}_{1}$ & $1: 0$ & 0 & 19 & & & 0 & 23 & & \\
\hline $\mathrm{BC}_{\mathrm{R}}$ & $1: 1$ & 7 & 45 & 27.8 & $<0.001$ & 0 & 60 & & $<0.001$ \\
\hline $\mathrm{BC}_{\mathrm{S}}$ & $0: 1$ & 2 & 283 & & & 2 & 302 & & \\
\hline $\mathrm{F}_{2}$ & $1: 3$ & 11 & 363 & 97.1 & $<0.001$ & 1 & 429 & 141 & $<0.001$ \\
\hline
\end{tabular}

a Early planted trials inoculated while plants were between the 7-leaf and row tassel growth stages.

b Late planted trials inoculated while plants were between the 4-leaf and 8-leaf growth stages.

${ }^{c}$ Hypothesized ratios for PI 186215 and Ames 19016 based on a single, dominant gene for resistance; ratios for PI 186209 and NSL 75976 based on a single, recessive gene for resistance.

d Chi-square value from a goodness-of-fit test based on the hypothesized ratio.

e Probability associated with the chi-square value from the goodness-of-fit test.

sora appeared to differ among four of these six accessions. The Argentine inbred 2-687 (PI 186215) conferred a chloroticfleck, hypersensitive-type resistance conditioned by a single, dominant gene. Similar to several other sources of chlorotic-fleck resistance $(3,6,7,10,22,30)$, the resistance in inbred 2-687 appeared to be allelic with or linked to the $R p p 9$ gene originally identified from South African accession PI $186208(19,29)$.

Resistance in Va59 (Ames 19016) was effective in $F_{1}$ progeny and appeared to be dominant and simply inherited; however, in inheritance and allelism trials, this resistance appeared to be a slow-rusting or incomplete resistance that was effective in adult plants but not in young seedlings. $\mathrm{Hu}$ et al. (9) also have observed differences in reactions of three-leaved seedlings and adult plants to $P$. polysora. In adult plants, fewer $P$. polysora uredinia formed on $\mathrm{BC}_{2} \mathrm{~F}_{2}$ families homozygous for the Rpl$D J$ compound gene for resistance to $P$. sorghi than on $\mathrm{BC}_{2} \mathrm{~F}_{2}$ families that carried the susceptible alleles $(r p 1 / r p 1)$. At the three-leaf growth stage, resistance to $P$. polysora did not differ among Rpl-DJ and $r p 1 / r p l$ families. The Rpl-DJ compound gene occurs in the same chromosomal region as the Rpp9 gene. However, based on our tests of allelism, the resistance in Va59 is not linked with the Rpp9 or Rpl-
DJ compound genes. The resistance in Va59 may be an additional source that can be useful in commercial maize in situations in which infection occurs after seedling stages, such as recent outbreaks of southern rust in the U.S. Corn Belt.

The resistance in PI 186209 (Venezuelan flint) and NSL 75976 (IA DS61) was not effective in hybrid combination $\left(\mathrm{F}_{1}\right.$ progeny) and, thus, probably has limited value in commercial maize. Resistance in PI 186209 may be conditioned by a single recessive gene and resistance in NSL 75976 may be co-dominant.

Resistant lines identified from this collection of accessions were not evaluated for reactions to multiple races of $P$. polysora or to populations of $P$. polysora common in tropical regions of the world. Isolates of $P$. polysora appear to differ in specific virulence $(2,19,28)$ even though the aecial stage is unknown and teliospores are not known to be functional (8) which, in theory, would slow the development of virulent races. Nevertheless, simply inherited resistance to $P$. polysora has not been durable in Africa or Hawaii $(25,28)$. Similarly, Roberts (17) observed in the early 1960s that four-leaved seedlings of the source of the Rpp 9 gene, PI 186208, were susceptible to 8 of $13 P$. polysora isolates evaluated, including isolates from Florida and Mexico. Subsequently, the Rpp 9 gene or a closely linked gene or genes was effective in trials in Florida, Mississippi, North Carolina, and China from the 1970s through $2006(3,6,7,10,16,22,30)$. Possibly, the $R p p 9$ gene or other simply inherited resistance to $P$. polysora, such as the resistance in Va59, may be effective for a prolonged period in situations where selection pressure is not intense, such as the U.S. Corn Belt. The Rpl-D gene, which conveys a similar type of chlorotic-fleck, hypersensitive resistance to $P$. sorghi, effectively controlled common rust in sweet corn in North America from the mid 1980s until 1999, when a virulent race occurred (15).

We did not extensively evaluate an Argentine accession, PI 198905 (4F-374 GE 3 ), or an accession from Uruguay, PI 186191 (inbred 627), that were resistant in our initial trial, due to a limited quantity of seed harvested from pollinations. Also, we did not evaluate an Argentine accession, PI 198902 (4F-345 CN 12), that was resistant to 9 of 13 isolates screened by Roberts (19). These and other accessions, particularly those from South America, may carry southern rust resistance genes other than the Rpp9 gene. Larger collections of $R p p$ genes and collections of virulent isolates of $P$. polysora would provide resources necessary to improve our understanding of the genetic mechanisms and molecular biology 
Table 5. Analysis of segregation to test resistance to Puccinia polysora in four plant introduction accessions for allelism with the Rpp 9 gene in early and late planted field trials in 2005

\begin{tabular}{|c|c|c|c|c|c|c|c|c|c|}
\hline \multirow{3}{*}{$\begin{array}{l}\text { PI source of resistance, } \\
\text { trials, and generations }\end{array}$} & \multirow{3}{*}{$\begin{array}{c}\begin{array}{c}\text { Hypothesized } \\
\text { ratio }^{c}\end{array} \\
\text { R:S }\end{array}$} & \multicolumn{4}{|c|}{ Early planted trial $^{\mathbf{a}}$} & \multicolumn{4}{|c|}{ Late planted trial ${ }^{b}$} \\
\hline & & \multicolumn{2}{|c|}{ Reaction of progeny } & \multirow[b]{2}{*}{$\chi^{2 \mathrm{~d}}$} & \multirow[b]{2}{*}{$P^{\mathrm{e}}$} & \multicolumn{2}{|c|}{ Reaction of progeny } & \multirow[b]{2}{*}{$\chi^{2 \mathrm{~d}}$} & \multirow[b]{2}{*}{$P^{\mathbf{e}}$} \\
\hline & & $\mathbf{R}$ & $\mathbf{S}$ & & & $\mathbf{R}$ & $\mathbf{S}$ & & \\
\hline B37Rpp9 & $1: 0$ & 60 & 0 & & & 67 & 0 & & \\
\hline Oh43Rpp 9 & 1:0 & 45 & 0 & & & 44 & 0 & & \\
\hline W64aRpp9 & $1: 0$ & 16 & 0 & & & 8 & 0 & & \\
\hline \multicolumn{10}{|c|}{ PI 186215 (Argentinean inbred 2-687) } \\
\hline $\mathrm{P}_{\mathrm{R}} \times R p p 9$ line & $1: 0$ & 58 & 0 & & & 56 & 0 & & \\
\hline$\left(\mathrm{P}_{\mathrm{R}} \times R p p 9\right.$ line $) \times \mathrm{P}_{\mathrm{S}}$ & $1: 0$ & 331 & 0 & & & 320 & 0 & & \\
\hline$\left(\mathrm{P}_{\mathrm{R}} \times R p p 9\right.$ line $) \mathrm{F}_{2}$ & $1: 0$ & 245 & 0 & & & 238 & 0 & & \\
\hline \multicolumn{10}{|l|}{ Ames 19016 (Va59) } \\
\hline $\mathrm{P}_{\mathrm{R}} \times \operatorname{Rpp} 9$ line & 1:0 & 20 & 0 & & & 26 & 0 & & \\
\hline$\left(\mathrm{P}_{\mathrm{R}} \times R p p 9\right.$ line $) \times \mathrm{P}_{\mathrm{S}}$ & $3: 1$ & 228 & 65 & 0.68 & 0.421 & 273 & 171 & 43.2 & $<0.001$ \\
\hline$\left(\mathrm{P}_{\mathrm{R}} \times \operatorname{Rpp} 9\right.$ line $) \mathrm{F}_{2}$ & $15: 1$ & 342 & 41 & 12.9 & 0.003 & 397 & 79 & 86.9 & $<0.001$ \\
\hline \multicolumn{10}{|c|}{ PI 186209 (Venezuelan flint) } \\
\hline$\left(\mathrm{P}_{\mathrm{R}} \times R p p 9\right.$ line $) \times \mathrm{P}_{\mathrm{S}}$ & $1: 1$ & 173 & 174 & 0 & 0.957 & 158 & 178 & 1.2 & 0.275 \\
\hline$\left(\mathrm{P}_{\mathrm{R}} \times R p p 9\right.$ line $) \mathrm{F}_{2}$ & $13: 3$ & 320 & 95 & 4.7 & 0.031 & 265 & 80 & 4.5 & 0.035 \\
\hline \multicolumn{10}{|l|}{ NSL 75976 (IA DS61) } \\
\hline $\mathrm{P}_{\mathrm{R}} \times R p p 9$ line & $1: 0$ & 40 & 0 & & & 47 & 0 & & \\
\hline$\left(\mathrm{P}_{\mathrm{R}} \times \operatorname{Rpp} 9\right.$ line $) \times \mathrm{P}_{\mathrm{S}}$ & $1: 1$ & 172 & 189 & 0.81 & 0.371 & 208 & 188 & 1.0 & 0.315 \\
\hline$\left(\mathrm{P}_{\mathrm{R}} \times R p p 9\right.$ line $) \mathrm{F}_{2}$ & $3: 1$ & 362 & 77 & 13 & $<0.001$ & 279 & 105 & 1.1 & 0.289 \\
\hline
\end{tabular}

${ }^{\mathrm{a}}$ Early planted trials inoculated while plants were between the 7-leaf and row tassel growth stages.

${ }^{\mathrm{b}}$ Late planted trials inoculated while plants were between the 4-leaf and 8-leaf growth stages.

${ }^{\mathrm{c}}$ Hypothesized ratios for PI 186215 based on a single gene allelic with the Rpp 9 gene; ratios for Ames 19016 based on a single, dominant gene independent from the Rpp 9 gene; ratios for PI 186209 based on a single, recessive gene for resistance; ratios for NSL 75976 based on resistance solely from the Rpp9 gene.

${ }^{\mathrm{d}}$ Chi-square value from a goodness-of-fit test based on the hypothesized ratio.

e Probability associated with the chi-square value from the goodness-of-fit test.

associated with this host-pathogen interaction.

\section{ACKNOWLEDGMENTS}

J. A. Chávez-Medina was supported through a USAID/Mexico TIES program administered through the University of Illinois and Universidad Autónoma de Querétaro.

\section{LITERATURE CITED}

1. Bailey, B. A., Schuh, W. Frederiksen, R. A., Bockholt, A. J., and Smith, J. D. 1987. Identification of slow-rusting resistance to Puccinia polysora in maize inbreds and single crosses. Plant Dis. 71:518-521.

2. Casela, C. R., and Ferreira, A. S. 2002. Variability in isolates of Puccinia polysora in Brazil. Fitopatol. Bras. 27:414-416.

3. Chen, C. X., Wang, Z. L., Yang, D. E., Ye, C.J., Zhao, Y. B., Jin, D. M., Weng, M. L., and Wang, B. 2004. Molecular tagging and genetic mapping of the disease resistance gene $R p p Q$ to southern corn rust. Theor. Appl. Genet. 108:945-950.

4. Fajemisin, J. M. 1976. Potentials for stable resistance to Puccinia polysora in local (Nigerian) and exotic maize varieties. Cereal Rusts Bull. 4:5-8.

5. Futrell, M. C. 1975. Puccinia polysora epidemics on maize associated with cropping practice and genetic homogeneity. Phytopathology 65:1040-1042.

6. Futrell, M. C., Hooker, A. L., and Scott, G. E. 1975. Resistance in maize to corn rust controlled by a single dominant gene. Crop Sci. 15:597-599.

7. Holland, J. B., Uhr, D. V., Jeffers, D., and Goodman, M. M. 1998. Inheritance of resistance to southern corn rust in tropical-by-cornbelt maize populations. Theor. Appl. Genet. 96:232-241.

8. Hooker, A. L. 1985. Corn and sorghum rusts. Pages 207-236 in: The Cereal Rusts, Vol. II. A. P. Roelfs and W. R. Bushnell, eds. Academic Press, Orlando, FL.

9. Hu, G., Webb, C. A., and Hulbert, S. H. 1997. Adult plant phenotype of the Rpl-DJ com- pound rust resistance gene in maize. Phytopathology 87:236-241.

10. Jines, M. P., P. Balint-Kurti, L. A. RobertsonHoyt, T. Molnar, J. B. Holland, and M. M. Goodman. 2007. Mapping resistance to southern rust in a tropical $\times$ temperate maize recombinant inbred topcross population. Theor. Appl. Genet. 114:659-667.

11. Leonard, K. J. 1974. Foliar pathogens of corn in North Carolina. Plant Dis. Rep. 58:532534.

12. Melching, J. S. 1975. Corn rusts: types, races, and destructive potentials. Pages 90-115 in: Annu. Corn Sorghum Res. Conf. 30th ASTA. Chicago.

13. Pataky, J. K., duToit, L. J., and Freeman, N. D. 2000. Stewart's wilt reactions of an international collection of Zea mays germ plasm inoculated with Erwinia stewartii. Plant Dis. 84:901-906.

14. Pataky, J. K., Michener, P. M., and Freeman, N.D. 1998. Sweet corn hybrid disease nursery-1998. Pages 105-115 in: Midwestern Vegetable Variety Trial Report for 1998. AES Bull. No. 777. Purdue University,

15. Pataky, J. K., and W. F. Tracy. 1999. Widespread occurrence of common rust, caused by Puccinia sorghi, on Rp-resistant sweet corn in the midwestern United States. Plant Dis. 83:1177.

16. Pataky, J., Williams, M., Warsaw, B, Meyer, M. and Moody, J. 2006. Sweet corn hybrid disease nursery-2006. Pages 59-74 in: Midwestern Vegetable Variety Trial Report for 2006. AES Bull. No. B18048. Purdue University,

17. Pavgi, M. S., and Flangas, A. L. 1959. Occurrence of southern corn rust in Wisconsin. Plant Dis. Rep. 43:1239-1240.

18. Raid R. N., Pennypacker, S. P., and Stevenson, R. E. 1988. Characterization of Puccinia polysora epidemics in Pennsylvania and Maryland. Phytopathology 78:579-585.

19. Robert, A. L. 1962. Host ranges and races of corn rusts. Phytopathology 52:1010-1012.

20. Rodriguez-Ardon, R., Scott, G. E., and King, S. B. 1980. Maize yield losses caused by southern corn rust. Crop Sci. 20:812-814.

21. Schall, R. A., McCain, J. W., and Hennen, J. F. 1983. Distribution of Puccinia polysora in Indiana and absence of a cool weather form as determined by comparison with $P$. sorghi. Plant Dis. 67:767-770.

22. Scott, G. E., King, S. B., and Armour, J. W., Jr. 1984. Inheritance of resistance to southern corn rust in maize populations. Crop Sci. 24:265-267.

23. Scott, G. E., and Zummo, N. 1989. Effect of genes with slow-rusting characteristics on southern corn rust in maize. Plant Dis. 73:114 116.

24. Sim, T., IV. 1980. Southern rust of corn recognized in Kansas. Plant Dis. 64:500.

25. So, Y. S., Ji, H. C., and Brewbaker, J. L. 2003. Genetics of resistance in tropical sweet corn to Puccinia polysora Underw. Maize Genet. Coop. Newsl. 77:32-33.

26. Storey, H. H., and Howland (Ryland), A. K. 1957. Resistance in maize to the tropical American rust fungus Puccinia polysora Underw. I. Genes Rpp1 and Rpp2. Heredity 11:289-301.

27. Storey, H. H., and Howland, A. K. 1959. Resistance in maize to the tropical American rust fungus Puccinia polysora. II. Linkage of genes Rpp1 and Rpp2. Heredity 13:61-65.

28. Storey, H. H., and Howland, A. K. 1967. Resistance in maize to a third East African race of Puccinia polysora Underw. Ann. Appl. Biol. 60:297-303.

29. Ullstrup, A. J. 1965. Inheritance and linkage of a gene determining resistance in maize to an American race of Puccinia polysora. Phytopathology 55:425-428

30. Uhr, D. V. 1991. Adaptation of tropical maize to temperate zones. Ph.D. dissertation (dissertation abstract 92-03177), North Carolina State University Raleigh.

31. White, D. G. 1999. Compendium of Corn Diseases, 3rd ed. American Phytopathological Society, St. Paul, MN.

32. Zummo, N. 1988. Components contributing to partial resistance in maize to Puccinia polysora. Plant Dis. 72:157-160. 